\title{
Bacillus endophthalmitis after cataract removal surgery following initial ocular trauma: a case report
}

Kamalul Khusus Khairil-Ridzwan ${ }^{1,2}$, W Mohd Mohd-Alif ${ }^{1,2}$, Hussein Adil ${ }^{1}$, Sivagurunathan Premala-Devi ${ }^{2}$, Zamri Noordin ${ }^{2}$, Ismail Shatriah ${ }^{1}$

${ }^{1}$ Department of Ophthalmology and Visual Science, School of Medical Sciences, Universiti Sains Malaysia, Kubang Kerian, Kelantan, Malaysia; ${ }^{2}$ Department of Ophthalmology, Hospital Raja Perempuan Zainab II, Malaysian Ministry of Health, Kota Bharu Kelantan, Malaysia

\section{Abstract}

Infectious endophthalmitis is an ocular infection caused by bacterial or fungal organisms involving intraocular tissues, aqueous, and vitreous humour. Bacillus sp. is an uncommon microorganism causing endophthalmitis. We describe a teenager who presented with a self-sealed corneal laceration, cataractous lens, and evidence of a breach in the anterior capsule. The eye was initially quiet and stable. The event started 1 day after uncomplicated cataract surgery. The patient developed fulminant postoperative endophthalmitis with a fatal final visual outcome. A high index of suspicion is mandatory, and more aggressive treatment may be able to improve the final outcome.

Keywords: Bacillus sp. infection, endophthalmitis, postcataract surgery, self-sealed corneal laceration

Correspondence: Kamalul Khusus Khairil-Ridzwan, Department of Ophthalmology and Visual Science, School of Medical Sciences, Universiti Sains Malaysia 16150 Kubang Kerian, Kelantan, Malaysia.

E-mail:drkhairedz@gmail.com 


\section{Abstrak}

Jangkitan endophthalmitis adalah penyakit jangkitan mata yang disebabkan oleh mikroorganisma seperti bakteria atau kulat yang melibatkan tisu intraokular, cecair aqueous, dan gel vitreous. Bacillus sp. adalah mikroorganisma yang sangat jarang ditemui sebagai penyebab jangkitan endophthalmitis. Kami ingin berkongsi mengenai seorang remaja dengan kecederaan kornea mata (luka mata) yang stabil, katarak, dan kapsul anterior kanta yang terkoyak akibat trauma. Kecederaan mata pesakit setelah mendapatkan rawatan awal bagi mengawal keradangan mata pada mulanya adalah stabil. Walaubagaimanapun keadaan mata yang cedera semakin teruk secara tiba-tiba selepas sehari pembedahan katarak dilakukan ke atas pesakit. Pesakit di diagnosakan sebagai jangkitan endophthalmitis selepas pembedahan dan boleh menyebabkan kadar penglihatan yang teruk atau kebutaan disebabkan oleh Bacillus sp. bakteria. Keadaan prasangka yang tinggi dan rawatan yang lebih agresif dalam merawat pesakit seperti ini mungkin boleh merubah keadaan kecederaan mata dan penglihatan pesakit selepas rawatan akhir.

Kata kunci: jangkitan Bacillus sp., jangkitan endophthalmitis, laserasi kornea yang tertutup sendiri, selepas pembedahan katarak

\section{Introduction}

Postoperative endophthalmitis is an ocular infection following intraocular surgery. The incidence following cataract surgery ranges from $0.08 \%$ to $0.7 \%{ }^{1}$ Although bacteria are the most commonly isolated microorganisms in postoperative endophthalmitis, isolating Bacillus $s p$. is rare, and most cases are related to trauma. In this case report, we describe a case of Bacillus sp. postoperative endophthalmitis in a boy with a history of ocular trauma.

\section{Case presentation}

A 17-year-old teenager presented to the casualty with alleged trauma of the right eye pricked by metal wire while repairing a motorbike. He sustained sudden onset of blurred vision and came to the hospital within hours of the trauma.

Visual acuity on presentation was hand movement in the right eye and $6 / 6$ in the left eye. Slit lamp ocular examination revealed a $1 \mathrm{~mm}$, self-sealed, full-thickness corneal laceration at the 7 o'clock peripheral cornea. The anterior chamber was deep with a mild degree of inflammation; no hyphaema or vitreous were seen in the anterior chamber. The lens was cataractous with evidence of anterior capsule breach and limited fundus view. The intraocular pressure was normal. 

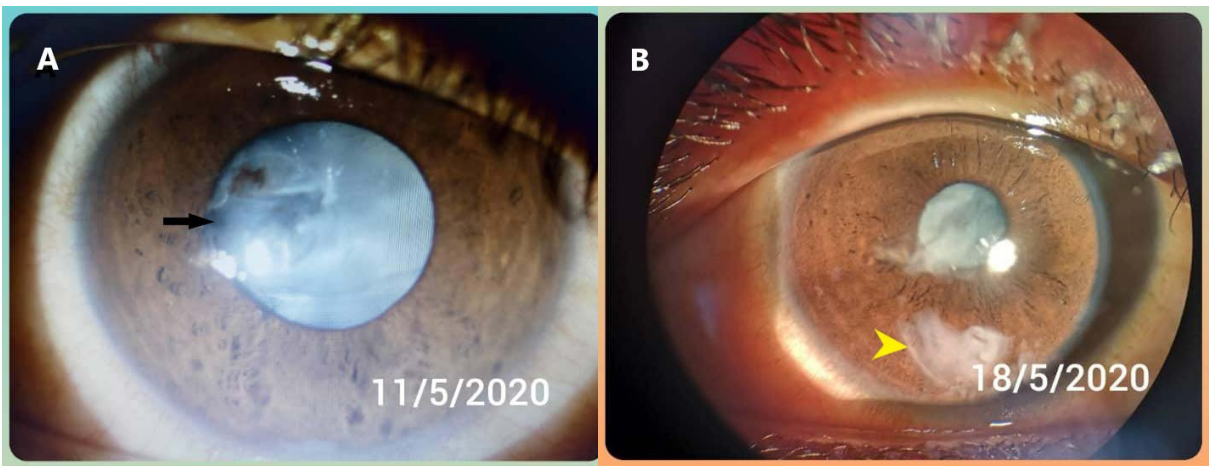

Fig. 1. (A) Post-traumatic penetrating injury with cataractous lens and anterior capsule breach. (B) Review 1 week after the initial trauma.

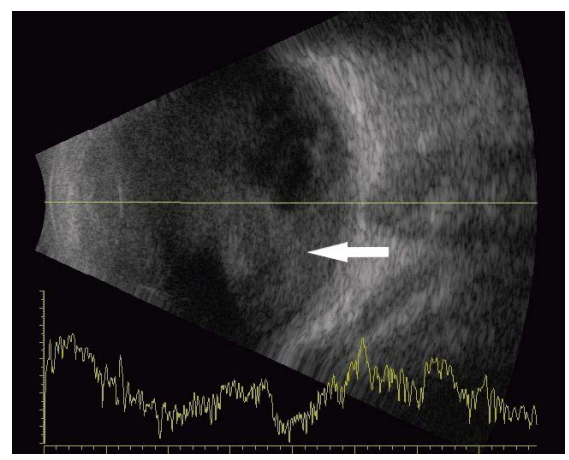

Fig. 2. B scan ultrasonography at day 1 postoperatively showing dense vitreous opacity.

Skull X-ray revealed absence of intraocular foreign body. He was admitted and started with intravenous ciprofloxacin $200 \mathrm{mg}$ every 12 hours. Gutt prednisolone acetate $1 \%$ and gutt moxifloxacin $0.5 \%$ were prescribed every 4 hours. At the 1-week review, cortical matter was spotted in the inferior anterior chamber (Fig. 1).

The patient underwent uneventful phacoemulsification surgery. There was a breach in the anterior and posterior capsules with anterior capsular fibrosis from 10 to 3 o'clock. During review at postoperative day 1 , the cornea was oedematous and hypopyon was present with fibrin plaque covering the visual axis. B-scan ultrasonography showed dense vitreous opacity; thus, he was diagnosed with acute postoperative endophthalmitis (Fig. 2).

An emergency intravitreal injection of vancomycin $1 \mathrm{mg} / 0.1 \mathrm{ml}$ and ceftazidime 2 $\mathrm{mg} / 0.1 \mathrm{ml}$ was performed. Anterior chamber washout was performed given a poor window for the posterior segment. The vitreous sample was taken for microscopic examination and culture. 
Hourly Gutt moxifloxacin $0.5 \%$ and gutt ceftazidime $5 \%$ as well as oral ciprofloxacin 500 mg every 12 hours were started postoperatively. The intravitreal antibiotics were repeated three times at 72-hour intervals. The vitreous sample grew Bacillus sp. He was closely monitored during the postoperative period. Despite treatment and close observation, two months after the surgery the eyeball was phthisic with no light perception.

\section{Discussion}

Endophthalmitis is a potentially devastating ocular infection complication. The incidence of postoperative Bacillus $s p$. endophthalmitis is rare and mostly seen in traumatic cases. ${ }^{2}$ Table 1 summarizes the published cases on Bacillus $s p$. postoperative endophthalmitis from 1997 to 2021, including our case.

Contamination of viscoelastic substances was reported in 14 patients with Bacillus sp. endophthalmitis by Roy et al. in $1997 .{ }^{3}$ Orsi et al. reported four cases with environmental contamination as the probable cause. ${ }^{4}$ Chan et al. described a similar case, but the cause of infection was unknown. ${ }^{5}$ We report one case of Bacillus sp. endophthalmitis with prior history of penetrating injury to the eye in which the endophthalmitis developed soon after cataract removal, which was performed 2 months after the initial injury. Our patient exhibited signs of anterior capsule breach after the initial injury. We postulate that Bacillus sp. may have lied dormant within the lens fibres after the initial injury and did not elicit moderate to severe inflammation.

The patients in the aforementioned studies were all treated with pars plana vitrectomy and intravitreal combination of tobramycin and vancomycin..$^{3-5}$ In contrast, our patient received three intravitreal injections of vancomycin and ceftazidime. Pars plana vitrectomy was not performed due to corneal haziness. Endoscopic vitrectomy has a role in hazy cornea cases, allowing early intervention and obviating the need for evisceration, but not statistically significant in case of Bacillus sp. infection. ${ }^{6,7}$ As a complication, all the above patients developed profound visual loss due to the endophthalmitis. ${ }^{3-5}$ This may suggest that this particular microorganism is highly virulent and provokes severe retinal necrosis. However, this postulation warrants histological confirmation and diagnosis.

\section{Conclusion}

In conclusion, Bacillus sp. is a rare causative microorganism in postoperative endophthalmitis. There is a possibility that it may lie dormant within the lens fibres after breaching the lens capsule. The final visual outcome is devastating. Prompt and aggressive treatment is necessary to treat this difficult eye condition. 


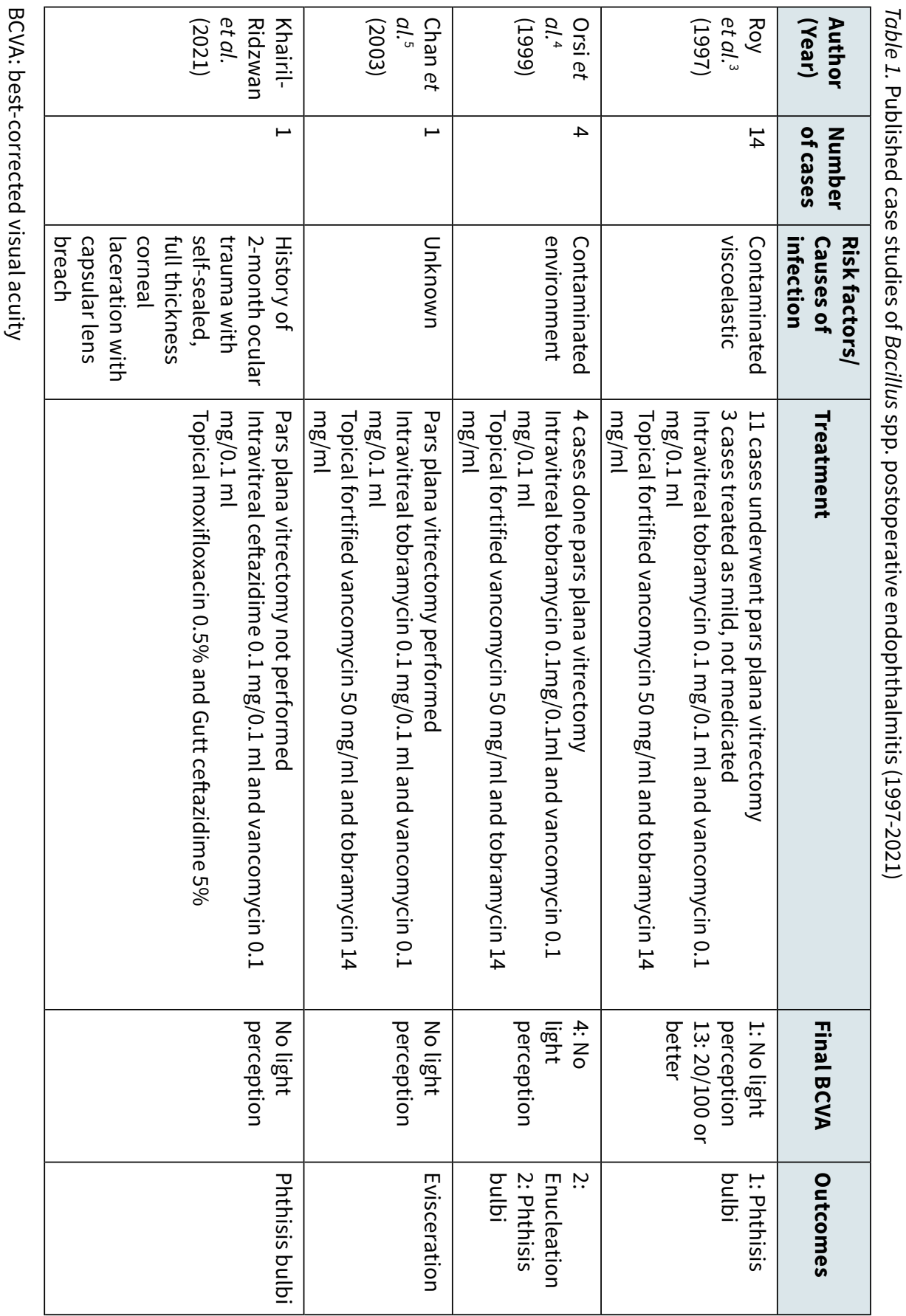




\section{Declarations}

\section{Ethics approval and informed consent}

Not required.

\section{Consent for publication}

The patient provided informed consent for the publication of the clinical data and images contained in this case report.

\section{Competing interests}

None.

\section{Funding}

None.

\section{Acknowledgements}

None.

\section{References}

1. Aaberg TM Jr, Flynn HW Jr, Schiffman J, Newton J. Nosocomial acute-onset postoperative endophthalmitis survey. A 10-year review of incidence and outcomes. Ophthalmology. 1998;105(6):10041010.

2. Callegan MC, Engelbert M, Parke DW, Jett BD, Gilmore MS. Bacterial endophthalmitis: Epidemiology, therapeutics, and bacterium-host interactions. Clin Microbiol Rev. 2002;15:111-124.

3. Roy M, Chen JC, Miller M, Boyaner D, Kasner O, Edelstein E. Epidemic Bacillus endophthalmitis after cataract surgery. Ophthalmology. 1997;104:1768-1772.

4. Orsi GB, Aureli P, Cassone A, Venditti M, Fara GM. Post-surgical Bacillus cereus endophthalmitis outbreak. J Hosp Infect. 1999;42:250-252

5. Chan WM, Liu DT, Chan CK, Chong KK, Lam DS. Infective endophthalmitis caused by Bacillus cereus after cataract extraction surgery. Clin Infect Dis. 2003;37(3): 31-34.

6. Dave VP, Pappuru RR, Tyagi M, Pathengay A, Das T. Endoscopic vitrectomy in endophthalmitis: initial experience of 33 cases at a tertiary eye care center. Clin Ophthalmol. 2019;13:243-251.

7. Pan Q, Liu Y, Wang R, et al. Treatment of Bacillus cereus endophthalmitis with endoscopy-assisted vitrectomy. Medicine. 2017;96(50):8701. 